\title{
Pembelajaran Matematika dengan Model Kooperatif Tipe Jigsaw untuk Meningkatkan Komunikasi Matematika Siswa pada Pokok Bahasan Perbandingan
}

\author{
Dadang Apandi ${ }^{1, a)}$, Rahayu Kariadinata ${ }^{2}$, dan Wati Susilawati ${ }^{2}$ \\ ${ }^{1}$ Prodi Pendidikan Matematika, UIN Sunan Gunung Djati Bandung, \\ Jl. A.H. Nasution No. 105, Cibiru , Bandung 40614, Indonesia \\ ${ }^{a)}$ E-mail: pmtk@uinsgd.ac.id
}

\begin{abstract}
Abstrak. Tujuan penelitian ini penulis mencoba menerapkan pembelajaran dengan model kooperatif tipe jigsaw dengan harapan dapat mengembangkan kemampuan komunikasi matematika siswa, meningkatkan minat siswa terhadap matematika, meningkatkan aktivitas siswa di kelas, dan meningkatkan kemampuan guru dalam mengelola kegiatan belajar mengajar, sehingga tercipta lingkungan belajar yang aktif dan kondusif. Metode penelitian yang digunakan adalah Penelitian Tindakan Kelas (PTK) terhadap siswa kelas VII.F MTsN Kota Bandung, dengan jumlah siswa sebanyak 39 siswa. Adapun instrumen yang digunakan adalah Lembar Aktifitas Siswa (soal-soal yang didiskusikan dikelompok ahli), tes setiap akhir siklus, tes akhir, lembar observasi dan sekala sikap. Hasil analisis data penelitian menunjukkan bahwa aktivitas siswa dalam pembelajaran matematika dengan metode kooperatif tipe jigsaw mengalami peningkatan. Begitu pula dengan tingkat kemampuan Komunikasi Matematikanya yang digambarkan dengan hasil penilaian dengan nilai memuaskan.
\end{abstract}

Kata Kunci. Jigsaw, Komunikasi matematika

\section{Pendahuluan}

Pendidikan pada dasarnya merupakan suatu kegiatan yang sangat kompleks dan di dalamnya terdapat suatu proses belajar mengajar yang keduanya tidak dapat dipisahkan. Pada tahun 1996, UNESCO menetapkan empat pilar utama pendidikan untuk abad 21, yaitu learning to know, learning to do, learning to be, dan learning to live together. Hal tersebut sebagai upaya dalam menghadapi tantangan globalisasi, persaingan bebas yang semakin ketat dan budaya yang semakin plural.

Matematika merupakan suatu pengetahuan yang mempunyai karakteristik mendorong siswa untuk berpikir logis, kritis, tekun dan inisiatif, sehingga diharapkan karakteristik ini terdapat pada siswa yang mempelajari matematika. Berbagai upaya ke arah peningkatan pembelajaran matematika terus dilakukan, misalnya dengan perbaikan terhadap strategi, metode serta teknik pelaksanaan pembelajaran. Tetapi yang diterapkan pada saat ini oleh sebagian besar guru lebih cenderung menggunakan pendekatan tradisional yang menekankan kepada latihan soal-soal atau practice, pembelajaran seperti ini merupakan proses matematika (doing matematic), sebab pada pembelajaran ini guru aktif dalam pembelajaran, sedangkan siswa hanya 
Pembelajaran Matematika Dengan Model Kooperatif Tipe Jigsaw untuk Meningkatkan Komunikasi Matematika Siswa Pada Pokok Bahasan Perbandingan

menerima dan meyelesaikan soal-soal, sehingga pembentukan hubungan antara berpikir dan berbuat selama kegiatan pembelajaran kurang diperhatikan yang menyebabkan kegiatan pembelajarannya menjadi kurang efektif dan kurang efisien, pembelajaran ini mengakibatkan siswa tidak mampu bepikir maksimal.

Demikian pula pembelajaran yang berlangsung di MTsN 1 Kota Bandung, hasil belajar siswa pada pelajaran matematika masih rendah. Kemudian, kemampuan komunikasi matematika yang merupakan salah satu tujuan umum pembelajaran matematika juga masih rendah

Dalam model belajar kooperatif tipe jigsaw, siswa dituntut untuk dapat mengembangkan daya berpikir, daya inisiatif dan kreatif sesuai dengan karakteristik dari matematika itu sendiri.

Berdasarkan permasalahan yang dikemukakan di atas, peneliti tertarik untuk mengadakan suatu penelitian dengan judul Pembelajan Matematika dengan Model Kooperatif Tipe Jigsaw untuk Meningkatkan Kemampuan Komunikasi Matematika Siswa pada Pokok Bahasan Perbandingan.

\section{Metodologi Penelitian}

Metode yang digunakan dalam penelitian ini adalah Penelitian Tindakan Kelas (PTK). Jenis data yang digunakan untuk memecahkan permasalahan dalam penelitian ini adalah data kualitatif dan data kuantitatif. Data kuantitatif diperoleh dari tes evaluasi (siklus I-siklus III) dan post tes, sedangkan data kualitatif diperoleh dari hasil observasi terhadap siswa dan guru pada saat pembelajaran berlangsung. Penelitian ini dilakukan di MTsN 1 Kota Bandung dengan subyek penelitian ini adalah siswa kelas VII.F semester ganjil MTsN 1 Kota Bandung sebanyak 40 siswa yang memiliki kemampuan heterogen. Adapun Instrumen yang digunakan untuk mengumpulkan data dalam penelitian ini adalah observasi dan tes.

\section{Hasil dan Pembahasan}

Berdasarkan hasil analisis data test formatif pada siklus I menunjukan bahwa jumlah siswa yang memiliki nilai di atas rendah adalah 25 siswa dengan rincian 6 siswa masuk kategori sangat baik, 4 siswa masuk dalam kategori baik 15 siswa masuk adalah kategori cukup. Hal ini berarti bahwa masih ada sejumlah siswa yang memiliki kategori nilai rendah 
sebanyak 10 siswa termasuk kategori kurang dan 2 siswa yang kateorinya jelek. Dengan demikian bila dihitung akan di peroleh rata - rata kemampuan komunikasi matematika siswa pada siklus I sebesar

\begin{tabular}{|c|c|c|}
\hline $\begin{array}{c}\text { Ukuran } \\
\text { Komunikasi } \\
\text { Matematika } \\
\text { Siswa }\end{array}$ & $\begin{array}{c}\text { Jumlah } \\
\text { Siswa }\end{array}$ & Kriteria Penilaian \\
\hline $90 \leq \mathrm{A} \leq$ & 10 & Sangat baik \\
100 & & Baik \\
\hline $75 \leq \mathrm{B}<90$ & 15 & Cukup \\
\hline $55 \leq \mathrm{C}<75$ & 9 & Kurang \\
\hline $40 \leq \mathrm{D}<55$ & 5 & Sangat Kurang \\
\hline $0 \leq \mathrm{E}<40$ & 0 & \\
\hline
\end{tabular}

$64,86 \%$ berarti termasuk kategori cukup.

Berdasarkan temuan-temuan yang di dapat pada siklus I serta hasil analisis data - data yang di peroleh dengan bantuan observer, di temukan beberapa kelemahan dan kekurangan yang terdapat pada siklus I ada beberapa hal yang perlu diperhatikan, agar pada siklus II terjadi perbaikan kemudian aktifitas siswa yang belum maksimal diupayakan dimaksimalkan pada siklus II.

Kondisi kemampuan komunikasi matematika siswa pada akhir pelaksanaan siklus II, jumlah siswa yang memiliki kategori nilai di atas rendah adalah 31 siswa, hal ini berarti masih ada sejumlah siswa yang memiliki kategori nilai rendah sebanyak 7 siswa. Dengan demikian bila dihitung, diperoleh rata-rata kemampuan komunikasi matematika siswa pada siklus II sebasar $71,79 \%$, berarti ada peningkatan sebesar $6,93 \%$ namun masih dalam katerori cukup.

Berdasarkan hasil analisis data terlihat gambaran kondisi kemampuan komunikasi matematika siswa pada akhir pelaksanaan siklus III, sebagaimana yang terlihat pada tabel 3.1.

Tabel 3.1.

Kriteria Penilaian Kemampuan Komunikasi Matematika Siswa

Dari tabel 3.1 di atas, menunjukkan bahwa jumlah siswa yang memiliki kategori nilai diatas rendah adalah 34 siswa. Hal ini berarti bahwa masih ada siswa yang memiliki katagori nilai rendah sebanyak 5 siswa. Dengan demikian bila dihitung diperoleh rata-rata kemampuan komunikasi matematika siswa pada siklus III ini sebesar $75,85 \%$, berarti nilai rata-ratanya meningkat $4,06 \%$ dari siklus II. Sehingga masuk dalam kataegori tinggi.

Sedangkan gambaran kondisi kemampuan komunikasi matematika siswa pada tes akhir dapat dilihat pada tabel 3.2 
Pembelajaran Matematika Dengan Model Kooperatif Tipe Jigsaw untuk Meningkatkan Komunikasi Matematika Siswa Pada Pokok Bahasan Perbandingan

Tabel 3.2

Kriteria Penilaian Kemampuan Komunikasi

Matematika Siswa

\begin{tabular}{|c|c|c|}
\hline $\begin{array}{c}\text { Ukuran } \\
\text { Komunikasi } \\
\text { Matematika } \\
\text { Siswa }\end{array}$ & $\begin{array}{c}\text { Jumlah } \\
\text { Siswa }\end{array}$ & $\begin{array}{c}\text { Kriteria } \\
\text { Penilaian }\end{array}$ \\
\hline $90 \leq \mathrm{A} \leq 100$ & 9 & Sangat baik \\
\hline $75 \leq \mathrm{B}<90$ & 12 & Baik \\
\hline $55 \leq \mathrm{C}<75$ & 14 & Cukup \\
\hline $40 \leq \mathrm{D}<55$ & 4 & Kurang \\
\hline $0 \leq \mathrm{E}<40$ & 2 & Sangat Kurang \\
\hline
\end{tabular}

Berdasarkan tabel 3.2 di atas jumlah siswa yang memiliki kategori nilai di atas rendah adalah 33 siswa, sedangkan 6 siswa termasuk kategori nilai di bawah rendah. Dengan demikian bila dihitung diperoleh rata-rata kemampuan komunikasi matematika siswa sebesar $71,30 \%$ berarti kemampuan komunikasi matematika siswa termasuk kategori baik.

Perkembangan tingkat kemampuan komunikasi siswa melalui pembelajaran dengan strategi jigsaw dilihat dari hasil tiap akhir siklus dan tes akhir setelah keseluruhan siklus selesai (post test). terlihat pada gambar 3.1.

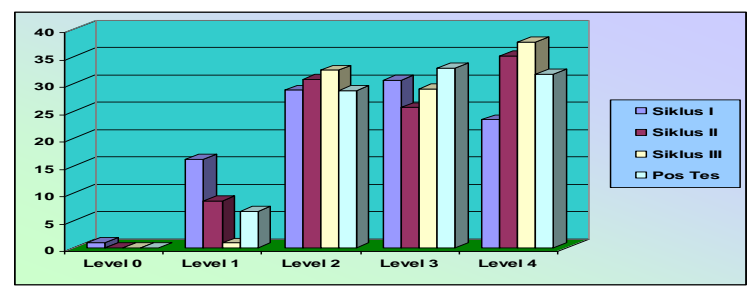

Jurnal Analisa Vol.1 No.2 Juni 2014 :50-56
Gambar 3.1

Grafik Kualitas Kemampuan Komunikasi

Matematika Siswa

Dari gambar diatas dapat diperoleh informasi bahwa kemampuan komunikasi matematika siswa mengalami peningkatan. Untuk mengetahui bagaimana sikap siswa terhadap pembelajaran metematika yang menggunakan strategi jigsaw dan soal-soal komunikasi matematika, siswa diberikan angket skala sikap.

Berdasarkan hasil analisis dapat disimpulkan tentang sikap positif dan sikap negatif siswa terhadap pembelajaran matematika yang menggunakan model kooperatif tipe jigsaw dan terhadap soalsoal komunikasi. Sikap positif dan sikap negatif siswa terhadap pembelajaran matematika yang menggunakan model kooperatif tipe jigsaw dapat dilihat dari pernyataan positif dan pernyataan negatif pada angket nomor 6 sampai dengan nomor 12 dan nomor 17 tentang pembelajaran matematika dengan tipe jigsaw. Rata-rata persentase sikap positif dan sikap negatif siswa secara rinci disajikan pada gambar 3.2 berikut: 


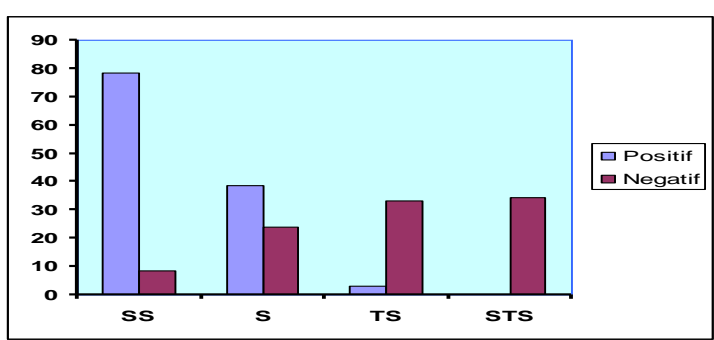

Gambar 3.2

Grafik Rata-rata Persentase Sikap Siswa Terhadap Pembelajaran

Model Kooperatif Tipe Jigsaw

Berdasarkan grafik tersebut terlihat bahwa sebagian besar siswa sangat setuju terhadap pembelajaran matematika model kooperatif tipe jigsaw. Hal ini terlihat dari persentase rata-rata siswa yang sangat setuju pada pernyataan positif dari pembelajaran matematika dengan model kooperatif tipe jigsaw, sebesar 64,6\%. Sedangkan sebagian besar siswa tidak setuju dan sangat tidak setuju pada pernyataan negatif dari pembelajaran tipe jigsaw, dengan persentase $33,3 \%$ dan $34,2 \%$. Hal ini mengindikasikan bahwa sebagian besar siswa tidak setuju jika pembelajaran tipe jigsaw tidak dilaksanakan.

\section{Simpulan dan Saran}

Berdasarkan hasil penelitian dan pembahasan mengenai meningkatkan kemampuan komunikasi matematika siswa melalui model pembelajaran kooperatif tipe jigsaw, maka diperoleh kesimpulan sebagai berikut: 1) Mengenai aktivitas guru dan siswa selama pembelajaran, dapat dikemukakan bahwa pembelajaran matematika dengan menggunakan model pembelajaran kooperatif tipe jigsaw dapat meningkatkan aktivitas siswa, dapat menciptakan kondisi sehingga siswa dapat berperan aktif dan mengurangi kecenderungan pembelajaran yang berpusat pada guru (teacher centered). Peran guru yang dominan adalah memberikan petunjuk/membimbing kegiatan siswa tersebut. 2) Kemampuan komunikasi matematika siswa dengan penerapan pembelajaran matematika dengan model pembelajaran kooperatif tipe jigsaw secara keseluruhan cukup baik. 3) Komunikasi Matematika pada keseluruhan siklus siswa menunjukan sangat baik. 4) Secara umum sikap siswa terhadap pembelajaran dengan model pembelajaran kooperatif tipe jigsaw dan soal-soal komunikasi matematika memberikan respon yang positif.

Berdasarkan kesimpulan, dikemukakan beberapa saran sebagai berikut : 1) Berdasarkan penelitian, pembelajaran matematika dengan model pembelajaran kooperatif tipe jigsaw, layak untuk dipertimbangkan menjadi salah satu pembelajaran dalam rangka meningkatkan komunikasi matematika siswa. Karena dengan pembelajaran ini, Jurnal Analisa Vol.1 No.2 Juni 2014 :50-56 
Pembelajaran Matematika Dengan Model Kooperatif Tipe Jigsaw untuk Meningkatkan Komunikasi Matematika Siswa Pada Pokok Bahasan Perbandingan

siswa cenderung lebih terlibat secara aktif dalam proses pembelajaran, sehingga dapat belajar lebih optimal. 2) Bagi guru yang akan menerapkan pembelajaran matematika dengan model pembelajaran kooperatif tipe jigsaw perlu memperhatikan materi yang tepat untuk disampaikan melalui pembelajara matematika dengan strategi jigsaw serta pemahaman dan penguasaan hakikat dan aturan Jigsaw. 3) Bagi peneliti yang akan mengadakan penelitian yang sama, karena pada kasus ini hanya terbatas pada materi Perbandingan dan sebagai upaya untuk meningkatkan kemampuan komunikasi siswa, mungkin ada baiknya dapat dicobakan pada materi yang lain misalnya untuk meningkatkan kemampuan komunikasi, penalaran ataupun koneksi matematika.

\section{Daftar Pustaka}

Afiifuddin,.H.M.M.,dkk， 2008， Potret Madrasah, Bandung, Insan Mandiri. Arikunto, S., 2002, Prosedur Penelitian Suatu Pendekatan Praktik, Jakarta Bumi Aksara.

Ansari, Bansu I. 2003,

Menumbuhkembangkan Kemampuan

Pemahaman dan Kmunikasi

Matematika Siswa SMU Melalui
Strategi Think-Talk-Write, Disertasi, Bandung: UPI, Tidak dipublikasikan. Kahmad, D., 2000, Metode Penelitian Agama, Jakarta : Pustaka Setia.

Dahar, R.W. , 1989, Teori-teori Belajar, Jakarta: Erlangga.

Cipta, Eliva S., 2006, Meningkatkan Kemampuan Komunikasi

Matematika Siswa SMP Melalui Strategi Think Talk Write., Skripsi, Universitas Islam Negeri SGD, Bandung, Tidak dipublikasikan.

Hamzah, 2004.Pembelajaran Matematika Menurut Teori Belajar Kontruktivisme,

http://www.depdiknas.go.id.

Kariadinata, R.,2001, Peningkatan Penmahaman Dan Kemampuan Analogi Matematika Siswa SMU Melalui Pembelajaran Kooperatif, Tesis, Bandung,UPI, Tidak dipublikasikan.

NCTM, 1989. Curriculum and Evaluation Standards for School Mathematics. Reston, VA: Authur. http://educare.e-fkipunla.net

NCTM,1996, Curriculum and Evaluation Standards for School Mathematics, Virginia: NCTM Inc.,. 2007, Pedoman Penulisan Karya Ilmiah, Bandung, UPI. 
Dadang Apandi, Rahayu Kariadinata, dan Wati Susilawati

— 2006, Peraturan Menteri

Pendidikan Nasional, Bandung, MK2MTs.

Wiriaatmaja, R., 2007, Metode Penelitian Tindakan Kelas, Bandung, Remaja Rosda Karya.

Russefendi, ET.,1988,Pengantar Kepada Guru Membantu Guru Mengembangkan Kompetensinya dalam Pengajaran Matematika untuk Meningkatkan CBSA, Bandung: Tarsito,.

Suherman, E dan Y. Sukjaya,1990, Evaluasi Pendidikan Matematika, Bandung: Wijayakusumah,.

Susilawati, W., 2008, Pelajar \& Pembelajaran Matematika, Universitas Islam Negeri SGD, Bandung.

Wihatma, U., Meningkatkan Kemampuan Komunikasi Matematika Siswa SLTP melalui Cooperative Learning Tipe Student TeamsAchievement Divisions (STAD), Tesis, Bandung UPI, Tidak dipublikasikan.

Rusmiati ,Y., 2005, Pembelajaran Matematika Melalui Strategi Think Talk Write Dalam Upaya Meningkatkan Pemahaman Siswa Pada Pokok Bahasan Program Linear, Skripsi, UIN Bandung. Yunawati, 2006, Pembelajaran Matematika Dengan Pemberian Kuis Dalam 